\title{
A rare anastomotic artery between right and left common iliac arteries: iliac anastomotic artery
}

\author{
Mehmet Ali İkidağ ${ }^{1}$, Mehmet Ali Cüce ${ }^{1}$, Şinasi Özkılıç ${ }^{2}$, Erdal Uysal ${ }^{3}$, Salih Murat Akkın ${ }^{4}$ \\ ${ }^{1}$ Department of Radiology, School of Medicine, SANKO University, Gaziantep, Turkey \\ ${ }^{2}$ Department of Nuclear Medicine, School of Medicine, SANKO University, Gaziantep, Turkey \\ ${ }^{3}$ Department of General Surgery, School of Medicine, SANKO University, Gaziantep, Turkey \\ ${ }^{4}$ Department of Anatomy, School of Medicine, SANKO University, Gaziantep, Turkey
}

\begin{abstract}
Congenital abdominal aortoiliac arterial abnormalities are not as common as aortic arch anomalies. Incidentally observed abdominal arterial and venous variations and anomalies are increasingly encountered due to widespread use of multislice CT for abdominal and vascular diseases. Knowledge of these variations or pathologies is crucial, especially before surgery to repair occlusive diseases, aneurysms and transplant surgeries, in order to reduce complications such as vascular injury and bleeding. Here we present an aortoiliac variation observed during abdominal CT examination of a 27-year-old female. This variation appeared as an anomalous arterial structure coursing obliquely and transversely between the right and left proximal common iliac arteries and binding them just below the bifurcation. Physicians should also be familiar with such a case, which appears as a triangular aortoiliac arterial window and which has only been reported in the old anatomical literature.
\end{abstract}

Keywords: anomaly; common iliac artery; variation

Anatomy 2018;12(1):53-55 @2018 Turkish Society of Anatomy and Clinical Anatomy (TSACA)

\section{Introduction}

Congenital abdominal aortoiliac arterial variations are not as common as aortic arch anomalies. ${ }^{[1,2]}$ Incidentally observed abdominal arterial and venous variations and anomalies are being encountered increasingly with the widespread use of multislice CT for abdominal and vascular diseases. Knowledge on these variations is crucial especially before surgeries to repair occlusive diseases, aneurysms, and transplant surgeries in order to reduce complications such as vascular injury and bleeding. Here we present an extremely rare common iliac artery variation observed during an abdominal CT examination.

\section{Case Report}

Abdominal CT examination of a 27 year old woman was performed in Gaziantep Dr. Ersin Arslan State Hospital with a 16 row multislice CT device (Siemens, Erlangen,
Germany) and obtained in arterial phase for suspected renal artery stenosis. The patient was referred to Department of Radiology in School of Medicine, SANKO University, Gaziantep, Turkey. Renal arteries, bilateral adrenal glands and other abdominal organs were evaluated as normal. An anomalous arterial structure between the proximal common iliac arteries in the aortoiliac region was noticed (Figure 1). This appeared as an anastomotic artery coursing obliquely and transversely between right and left proximal common iliac arteries, connecting them just below the bifurcation and causing an appearance of a triangular aortoiliac arterial window. The bifurcation was at L4-L5 disc level as usual, the iliac bifurcation angle was measured as $24^{\circ}$, narrower than expected. There were no atherosclerotic plaques, aneurysm, stenosis or other accompanying variations or pathologies. Other abdominal and pelvic arte-

This study was presented at XXIV International Symposium on Morphological Sciences, 2-6 September, 2015, Istanbul, Turkey. 
rial and venous structures were normal. The images were final at the level of internal-external iliac bifurcation. The patient had no signs of limb ischemia or claudication, so we did not perform any other CT study not to expose the patient to further ionizing radiation. The arterial system of both limbs was normal in Doppler sonography examination.

\section{Discussion}

Congenital malformations of the iliac bifurcation and iliac arteries are seldom encountered in man. In a previous study including 8000 angiograms, only 6 cases of aortoiliac and iliofemoral variations were found. ${ }^{[2]}$ Besides the origin, angulation, course, length, diameter and branching variability, the described anomalies associated with the common iliac artery include its congenital absence or hypoplasia and the persistent sciatic artery. ${ }^{[3-9]}$ The absence of common iliac artery in most of mammals is a normal pattern. On the contrary, absence of common iliac artery in humans has only been described in a few isolated case reports. ${ }^{[10-15]}$

Although a very rare anomaly, the persistent sciatic artery is also a well-known entity. As a branch of the umbilical artery, the earliest fetal blood supply to the developing lower extremity, it persists in the adult and is associated with a high incidence rate of complications that include aneurysm formation, embolism and nerve compression. ${ }^{[12,14]}$ Based on angiograms, the incidence of persistant sciatic artery has been reported as $0.025 \%$ to $0.04 \%$, and it is concluded that the persistent sciatic artery is a branch of the internal iliac artery and can occasionally originate from common iliac artery. ${ }^{[16]}$

According to the classical textbooks the common iliac artery in adults does not give any substantial branch. ${ }^{[6]} \mathrm{In}$ a large series of cadavers, only $35 \%$ had at least one lateral branch of common iliac artery. ${ }^{[3]}$ However, it is known that common iliac artery sends small branches to the peritoneum, psoas major, ureter, adjacent nerves and surrounding areolar tissue. The common iliac artery occasionally gives rise to the iliolumbar artery and accessory or replaced renal arteries if the kidney is ectopic. ${ }^{[6,1]}$ Initially, the renal arteries are branches of common iliac arteries, later the kidneys receive their blood supply from the aorta. ${ }^{[17]}$

Embryological development of aorta is formed during the third week of gestation. Two pairs of aortas are present at this stage. The dorsal aortas unite to form the descending aorta that passes the length of the embryo with $3 \mathrm{~mm}$ crown-heal length. ${ }^{[10]}$ The abdominal part of

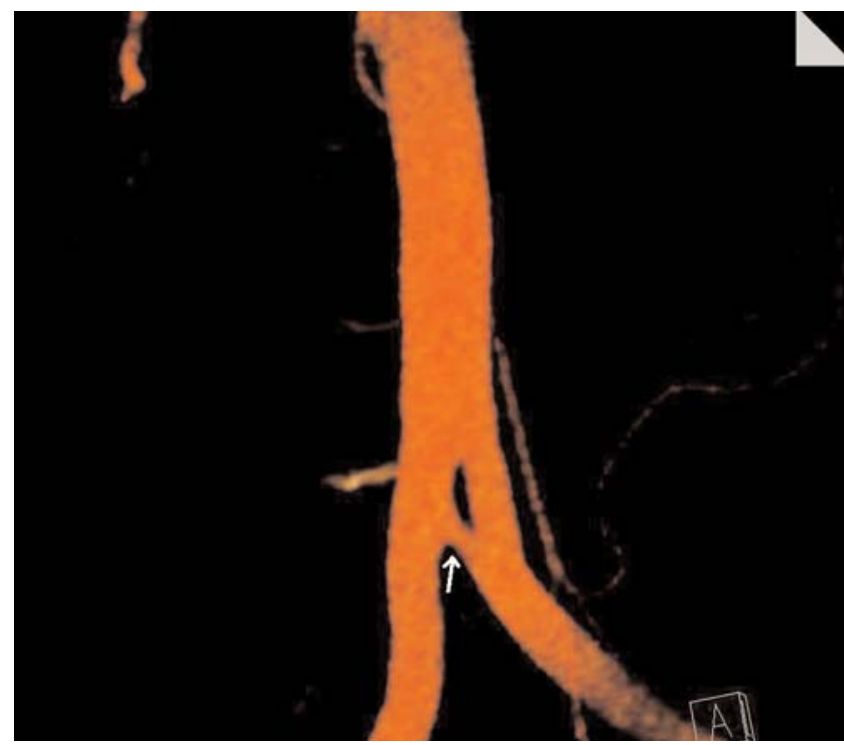

Figure 1. Coronal colored maximum intensity projection (MIP) image demonstrates an anomalous anastomotic artery between proximal common iliac arteries (arrow). [Color figure can be viewed in the online issue, which is available at www.anatomy.org.tr]

aorta has five posterolateral intersegmental (lumbar) branches. The lumbar arteries remain segmental arteries, but the more important fifth artery forms the main artery for the leg, the common iliac artery. Caudal to the fifth lumbal artery, the aorta regresses to the small median sacral artery. At the embryo stage of crown-heal length of $10 \mathrm{~mm}$, several side branches of the fifth lumbar artery can readily be identified: external iliac, sciatic, superior gluteal and internal pudendal arteries. One of these, the sciatic artery is the main artery of the lower extremity. ${ }^{[5-7,12,17]}$ The umbilical arteries are one of the paired ventral branches of fetal abdominal aorta. They are much larger than all other brunches of aorta and remain paired vessels. Longitudinal anastomoses to the fifth lumbar artery develop and initial aortic origins disappear. $^{[12]}$

This anomaly in our case may be due to incomplete coalescence of the distal parts of dorsal aorta pairs, or a possible persisting transverse anastomosis between the umbilical arteries during the development of longitudinal connections to the fifth lumbar artery.

The classical works on arterial variations never describe such a variant. ${ }^{[6,10,12]}$ An anatomic abnormality similar to our case has only been reported in the old anatomical literature. ${ }^{[1]]}$ To our knowledge, this is the first radiologic anatomic report of this extremely rare anomaly between two common iliac arteries. Physicians 
should be familiar with such a case, and consideration of such arterial variation may provide better outcomes in retroperitoneal surgeries, in the placement of large access catheters and devices used for interventions.

\section{References}

1. Ergun E, Şimşek B, Koşar PN, Yılmaz BK, Turgut AT. Anatomical variations in a branching pattern of arcus aortae: 64-slice CTA appearance. Surg Radiol Anat 2013;35:503-9.

2. Greebe J. Congenital anomalies of the iliofemoral artery. J Cardiovasc Surg (Torino) 1977;18:317-23.

3. El Mamoun BA, Demmel U. The lateral branches of common iliac artery. Surg Radiol Anat 1988;10:161-4.

4. Cope L. Common iliac artery arising from the renal artery. Clin Radiol 1995;50:200.

5. Kau T, Sinzig M, Gasser J, Lesnik G, Rabitsch E, Celedin S, Eicher W, Illiasch H, Hausegger KA. Aortic development and anomalies. Semin Intervent Radiol 2007;24:141-52.

6. Standring $\mathrm{S}$ (editor). Gray's anatomy. The anatomical basis of clinical practice. 40th ed. Edinburgh: Churchill Livingstone Elsevier; 2008. p. 1086.

7. Özgüner G, Sulak O. Development of the abdominal aorta and iliac arteries during the fetal period: a morphometric study. Surg Radiol Anat 2011;33:35-43.

8. Tekgündüz KŞ, Ceviz N, Kantarcı M, Demirelli Y, Olgun H, Caner İ, Şahin İO, Yolcu C. Rare cause of absence of femoral arterial pulse: bilateral common iliac artery hypoplasia. Pediatr Int 2014;56:90910.
9. Kaufman JA. Abdominal aorta and pelvic arteries. In: Kaufman JA, editor. Vascular and interventional radiology: the requisites. 2nd ed. Philadelphia, PA: Elsevier Saunders; 2014. Chapter 10, p. 199-228.

10. Adachi B. Das Arteriensystem der Japaner. Bd. II. Kyoto: Verlag der Kaiserlichen Japanischen Universität; 1928. p. 89.

11. Bergman RA, Afifi AK, Miyauchi R. Common iliac artery. Illustrated encyclopedia of human anatomic variation: Opus II: Cardiovascular system: Arteries: Pelvis. Available at: http://www.anatomyatlases.org/ AnatomicVariants/Cardiovascular/Text/Arteries/CommonIliac.sht $\mathrm{ml}$ (retrieved: 10 November 2015).

12. Lippert H, Pabst R. Arterial variations in man. Classification and frequency. Munich: JF Bergman Verlag; 1985. p. 3, 23, 60.

13. Shetty S, Kantha L, Sheshgiri C. Bilateral absence of common iliac artery - a cadaveric observation. International Journal of Anatomical Variations 2013;6:7-8.

14. Llauger J, Sabate JM, Guardia E, Escudero J. Congenital absence of the right common iliac artery: CT and angiographic demonstration. Eur J Radiol 1995;21:128-30.

15. Tay CM, Siew EP, Ng TK, Vathsala A, Tiong HY. Kidney transplantation in a patient with absent right common iliac artery and congenital renal abnormalities. Int J Surg Case Rep 2015;10:138-41.

16. Sabanciogullari V, Salk I, Yanastas M, Cetin A. Persistent sciatic artery originating from left common iliac artery. PakJ Med Sci 2011; 27:220-2.

17. Moore KL, Persaud TVN. The developing human. Clinically oriented embryology. 8th ed. Philadelphia: Elsevier Saunders; 2008. p. 249-51.

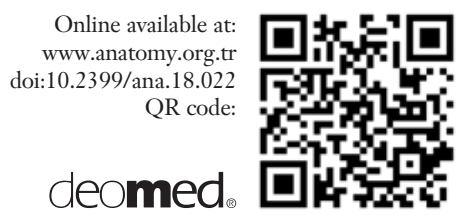

Correspondence to: Mehmet Ali Ikidağ, MD Department of Radiology, School of Medicine, SANKO University, Gaziantep, Turkey Phone: +90 3422115000 e-mail: maikidag@sanko.edu.tr

Conflict of interest statement: No conflicts declared.

This is an open access article distributed under the terms of the Creative Commons Attribution-NonCommercial-NoDerivs 3.0 Unported (CC BY-NCND3.0) Licence (http://creativecommons.org/licenses/by-nc-nd/3.0/) which permits unrestricted noncommercial use, distribution, and reproduction in any medium, provided the original work is properly cited. Please cite this article as: İkidağ MA, Cüce MA, Özkılıç Ş, Uysal E, Akkın SM. A rare anastomotic artery between right and left common iliac arteries: iliac anastomotic artery. Anatomy 2018;12(1):53-55. 